\title{
Factors Contributing to Students' Academic Performance in the Education College at Dammam University
}

\author{
Hassan Yahya Alfifi ${ }^{1}$, Jalila Abed ${ }^{2}$ \\ ${ }^{1}$ Mathemathics, College of Education, Dammam University, Dammam, Saudi Arabia \\ ${ }^{2}$ Mathematical Economics and Econometrics, Higher School of Economic and Commercial Sciences of Tunis, ESSEC, Tunisia
}

Email address:

hyalfifi@uod.edu.sa (H. Y. Alfifi), jalilaabed@yahoo.ca (J. Abed)

\section{To cite this article:}

Hassan Yahya Alfifi, Jalila Abed. Factors Contributing to Students' Academic Performance in the Education College at Dammam University. Education Journal. Vol. 6, No. 2, 2017, pp. 77-83. doi: 10.11648/j.edu.20170602.11

Received: October 18, 2016; Accepted: January 18, 2017; Published: March 5, 2017

\begin{abstract}
The objective of this research was to identify and analyze different factors influencing academic achievement. A survey was conducted by using a questionnaire for information gathering about learning preferences, entry qualifications, class size, number of hours studying, student's competence in English, gender, age, family income, parents' education level and students' area. The result of their first-grade annual examination gauged the academic performance. Pearson's correlation coefficient, multiple regression analysis, independent samples t-test and non-parametric test were used to analyze the data collected. The estimated effect of studying indicates that student's learning preferences, number of daily study hour and secondary average positively affect student's achievement, also, English language level has a positive influence on students' academic performance. The results show that female perform better than male students and married students realize significantly more academic success than single. While, class size, age, residential area of student, family size, family income and parents' education level have no significant influence.
\end{abstract}

Keywords: Academic Achievements, Learning Preferences, Gender, Age, Entry Qualifications, Parental Education

\section{Introduction}

Education is a primary need in this era of globalization. In every field, highly qualified people are needed. As Battle J. and Lewis M. (2002) states; "In this era of globalization and technological revolution, education is considered as a first step for every human activity. It plays a vital role in the development of human capital and is linked with an individual's well-being and opportunities for better living". Education is fundamental to the social and economic development of the world and the students' academic achievement is the outcome of education. It is generally assumed that the students who showed higher education performance also performed better in their professional life. In this context, Student academic performance has received considerable attention. But, as it can be seen from the literature, the previous studies have focused on students' performance in America (Romer, 1993) and Europe (Ilie S. and Lietz P., 2010). However, cultural differences between western societies and traditional middle eastern societies, may play a role in shaping the factors that affect this performance. In this context, it is very important to examine those relevant factors to Saudi Arabia students' population.

Specifically, this study targets to identify factors affecting university students' academic performances in the College of education at Dammam University in Saudi Arabia. There are two separate campuses, one for female and one for male students, so, we will analyze how this factors affect performance of both the genders

Students' academic performance is affected by numerous factor besides gender, age of student, class size, entry qualification of students, daily study hour, and English language level. Socioeconomic status is one of the most researched and debated factor among educational professionals that contribute towards the academic performance of students. The low socioeconomic status affects negatively the quality of student's academic 
performance, so we add parent's education background, family social economic status and residential area of student. Students are affected to the College of education according to their secondary score, measured by the variables entry qualification of students, so we will compare students' academic performance per learning preferences.

By analyzing the effect of entry qualifications on student performance in a field, educators can have an idea on necessary minimum entry requirement to success, it will be important to review the criteria for admissions. The finding of this study may motivate students to analyze their situations, and can be helpful for parents to solve the students' problems, to achieve quality education.

Understanding the numerous factors that benefit and hinder the academic progress of an individual's education is very important, this can help academics in designing strategies that can improve learners' academic achievements and improve the efficiency of education.

\section{Literature Review}

\subsection{Student Academic Achievement}

In the literature, diverse measures evaluate Academic achievement. We measure Academic performance by the grade point average through end of the first semester overall course marks, GPA, Galiher (2006) and Darling (2005).

\subsection{Factor Effect}

Numerous studies have been carried out to identify and analyze the range of factors which can affect the students' academic performance (Waters and Marzano, 2006, Anderson and Benjamin, 1994). Although, there is no commonly agreed on the role of all factors contributing effectively for academic success, researchers focus on internal and external classroom factors. Internal classroom factors such, entry qualifications, student's competence in English, learning preferences, class size, number of hours studying, external factors explore demographic and socioeconomic (Ballatine, 1993) classroom factors include family income, parents' education level, students' area, gender, and age, also, we can control for other variables that can explain academic success.

One of the important requirement for admission in the university is the average rate which called Maozuna ${ }^{1}$. Entry qualification are used to admit student in a field is based on the weighted average in the secondary school class. A student admitted with higher entry requirements is more able to success the program than a student recruited with the minimum admission criteria. Exploring the possible effects of entry qualifications on student performance, would allow admission decisions to be based on projections of academic

${ }^{1}$ The average rate can be calculated as follows: Maozuna $=$ The average rate $(100 \%)=$ General aptitude test $(\mathrm{GAT})(40 \%)+$ Achievement test (SAAT) $(40 \%)+$ High school Certification $(30 \%)$ performance. It is important to identify students who might need extra attention based on level of prior competencies upon admission.

Harb and Shaarawi (2006) found that student's competence in English has the most positive impact on students' performance. The students with strong communication skills in English, are more able to success their courses. A positive relationship is to verify between English level of students and students' performance.

When students are studying in their preferred choice, their motivations, and engagements play an important role in learning, they will perform better. A positive relationship between motivation and academic performance has been established by Zimmerman, Bandura, and Martinez-Pons (1992).

When reviewing the literature on the effect of class size in higher education, no agreement exists. Williams, Paul, Bill Quinn and Randall (1985), Pascarella and Terenzini (1991, 2005) concluded that the overall evidence suggests that class size plays no or little influence on student performance. However, McKeachie $(1980,1990)$ argued that class size is the primary variable that policy maker must contend with when developing effective teaching strategies. In smaller classroom, instructors are more likely to involve students in projects and real life activities, assign projects that require original or creative thinking, promoting critical thinking, solving advanced problem, form teams or discussion groups to facilitate learning.

The influence of time studying on student performance was not well explored, who spends more hours on studying will perform and those spending fewer hours fail to get high grades. For student attendance, it is obligatory in the College of education, this will improve academic performance.

Students having financial problems should face various hurdles, their basic needs remain unfulfilled. In fact, their financial problems distract them from their studies and they fail to perform better academically.

Educated parents can better understand the educational needs and their children's aptitude. They can help their children in their early education which affects their proficiency in their relative area of knowledge. Belonging to strong financial background, parents can provide latest technologies and facilities in a best possible way to enhance educational capability of their children. Students' whose fathers are highly qualified achieve high Scores.

Students who live far from the university area are more likely to have lower educational outcomes in terms of academic performance. Costs, availability of transport and fatigue affect negatively students' performance.

Educational performance at school has also been found to vary according to the student's sex (Horne, 2000). Certain reviews of the evidence suggest that boys suffer an educational disadvantage relative to girls. However, it is also observed that many of the researchers are not agree with this view point. Borde (1998) found no evidence of academic performance being influenced by gender.

The influence of age on academic achievement has been 
investigated in numerous research with widely differing conclusions (Haist, Wilson, Elam, Blue, and Fosson, 2000). Regarding the issue of student age, recent changes in educational policies around the world have led to an increase in the number of mature age admissions in educational institutions.

While a large proportion of undergraduate students are still 18 year olds, the ages of students in classes are now more variable, students entering university directly after secondary school, and there is who are returning to university. Students who were 19 years of age and younger, on their first year at the university, were classified as young students, while students who are greater than 19 years are classified as a mater student ${ }^{2}$.

Mature students are thought to lack basic skills required for effective study or to be impaired by age-related intellectual deficits. It should, however be pointed out that this comparison depends on the subject matter and types of assessment used. Richardson V. (1994) concludes his study by seeing that mature students were rather more likely than younger students to adopt a deep approach or a meaning orientation towards their academic work, and they were conversely less likely than younger students to adopt a surface approach or a reproducing orientation (Victor M., 2011).

\section{Methodology and Procedure}

\subsection{Data Collection}

Dammam University, in Kingdom of Saudi Arabia is a public university. It has 21 colleges, and a student population of over 45,000. It offers a variety of degree programs in Health, Engineering, Science and management, and Art and education. This study was carried out in the College of Education. The College of Education is specialized in the preparation of qualified professional teachers both academically and professionally.

Participants were 300 students, male and female, taken from randomly selected groups, taking course in the College of education for the 2015/2016 academic year, in undergraduate programs, Education in Elementary Grades Teacher Education, Education in Kindergarten and Education in Qur'anic Studies Data is collected from participants through questionnaire.

The survey instrument consisted of 14 questions based on factors that influence academic performance. These factors included demographic and socioeconomic factors, entry qualification (high school Certification) and student academic achievement. The participation in the survey was voluntary and their anonymity was guaranteed. Students were not required to supply identifying information on the survey instrument thus guaranteeing anonymity and the objectives of the survey were explained

${ }^{2}$ In the United Kingdom, a mature student who is age is 21 years, while for United States of America is 22 years and in Australia a 25 year old students is being classified as mature students (Trueman and Hartley, 1996). to students.

\subsection{Data Analysis}

Data Collected allowed us to control for the influence of several factors on student educational performance where, entry qualifications, student's competence in English, learning preferences, class size, number of hours studying, family income, parents' education level, students' area, gender, age, are independent variables and academic achievements computed as the final grades obtained from the overall course of the first semester (2016) for each student is the dependent variable.

Students who entered semester 1 of 2016 are 300, with a $100 \%$ response rate, we delete 12 observations because the information was incomplete. 288 questionnaires from the surveyed students were used, of which $23,6 \%$ are students in Education in Kindergarten, 61,4\% in Education in Elementary Grades Teacher Education, and $15 \%$ in Education in Qur'anic Studies, in overall, 50\% are female.

Data collected from questionnaire were first analyzed using descriptive statistics. Pearson's correlation coefficient, independent samples t-test, non-parametric test and multiple regression analysis, were used to analyze the data collected.

By analyzing Graph 1, the repartition of student's academic achievement, $19 \%$ of students are in risk $(30 \%$ for male students and $8 \%$ for Female students), $15 \%$ of students have low Scores, $28 \%$ have medium scores and only $31 \%$ of students have excellent scores. We note that only $14 \%$ of male student have excellent scores however, $48 \%$ of female students realize excellent scores.

We note a strong positive correlation between the gender and the performance academic and between the performance academic and the number of hours of studying, also we note a positive relation between the gender and the English level, and between academic performance at secondary school and academic performance at university. We found a significant negative relation between parent education and their income (Table A1, Annex).

Table 1 shows that, on average, the class size is 27 students, students in our sample report studying 4.38 hours per day, the family size is 6 persons. The secondary average mean is about 90, but the mean of GPA is only 66.47. $85.7 \%$ of the respondents were classified as young students (less than 20) and $14.3 \%$ were classified as mature students.

Comparing male and female students, female students tend to perform more than male students, on average, female student's performance (74.71) is higher than male student's achievement (58.34), This result is consistent with previous studies by Munyaradzi G. (2013). Female students have higher GPA, have higher secondary score, and study more. For male students and compared to their female counterpart, their classes are more crowded. 


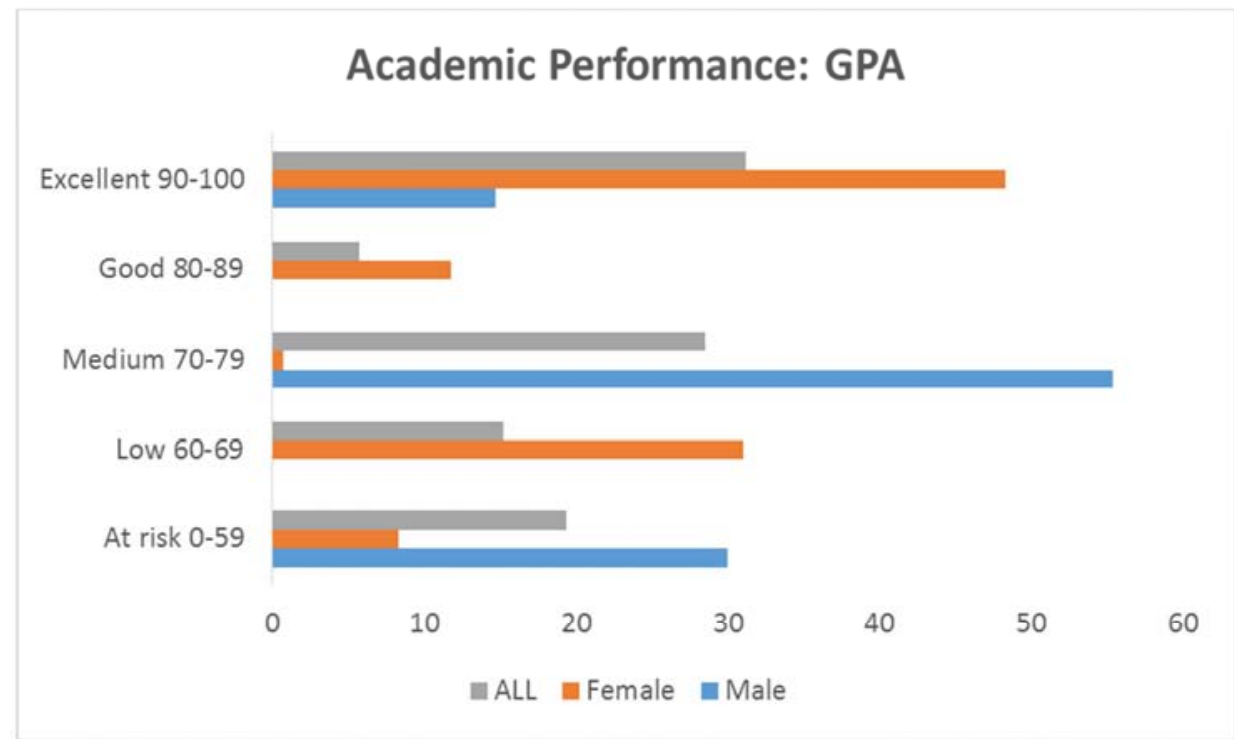

Figure 1. Academic Performance: GPA by gender.

Table 1. Students Characteristics by Gender.

\begin{tabular}{lllll}
\hline Variables & All & Female & Male & T- Test P-Value \\
\hline & Mean (Std. Deviation) & Mean (Std. Deviation) & Mean (Std. Deviation) & \\
\hline Hours & $4.38(0.96)$ & $4,75(1,02)$ & $4,01(0,75)$ & 0,000 \\
AveSec & $90.56(7.35)$ & $93,18(5,25)$ & $87,97(8,17)$ & $0,000^{*}$ \\
Average & $66.47(18.40)$ & $74,71(16,55)$ & $58,34(16,45)$ & 0,000 \\
Age & $19.57(1.48)$ & $19,63(1,51)$ & $19,50(1,45)$ & 0.455 \\
Size & $26.15(6.87)$ & $24,68(7,33)$ & $27,64(6,04)$ & 0,000 \\
Observation & 288 & 143 & 145 & \\
\hline
\end{tabular}

*Man Witney Test, the AveSec variable is not normally distributed.

Descriptive statistics (Table 2) also indicate that married students are more likely to perform than single students (only for female). Students' achievement is related to student's sense of belonging to their field, students who dislike their field perform lower. On average, Students located near the university were equally as likely as who located far from the university. However, there is ample evidence that the family environment has a strong effect on student's academic success. Also, student's achievement varied considerably among English skills, the difference in mean is significant, academic English proficiency is a key to student achievement.

Table 2. Difference in Academic Performance.

\begin{tabular}{|c|c|c|c|c|c|}
\hline Variables & Modalities & Mean & Std. Deviation & P-Value & Observations \\
\hline \multirow{3}{*}{ Field } & Education & 69.76 & 65.86 & \multirow{3}{*}{$0,000 * *$} & 68 \\
\hline & Kindergarten & 62.74 & 60.02 & & 177 \\
\hline & Quranic & 76.62 & 71.50 & & 43 \\
\hline \multirow{2}{*}{ Like } & $\mathrm{No}=0$ & 64.07 & 1.15 & \multirow{2}{*}{$0.207 *$} & 26 \\
\hline & Yes $=1$ & 66.70 & 2.94 & & 262 \\
\hline \multirow{2}{*}{ Gender } & Male $=0$ & 58.34 & 1.36 & \multirow{2}{*}{$0.000^{*}$} & 145 \\
\hline & Female $=1$ & 74.71 & 1.38 & & 143 \\
\hline \multirow{2}{*}{ Status } & Single $=0$ & 66.20 & 18.71 & \multirow{2}{*}{$0,21 *$} & 261 \\
\hline & Maried=1 & 69.11 & 15.10 & & 27 \\
\hline \multirow{2}{*}{ Area } & Near $=0$ & 65.97 & 1.52 & \multirow{2}{*}{$0.97 *$} & 141 \\
\hline & Far from $=1$ & 66.94 & 1.54 & & 147 \\
\hline \multirow{2}{*}{ Partedu } & Secondary & 65.96 & 1.46 & \multirow{2}{*}{$0.95^{*}$} & 129 \\
\hline & University & 67.10 & 1.61 & & 159 \\
\hline \multirow{2}{*}{ English } & Beginner & 60.97 & 1.84 & \multirow{2}{*}{$0,000 * *$} & 92 \\
\hline & Advance & 74 & 3.31 & & 34 \\
\hline
\end{tabular}

*Test de Kolmogorov-Sminorv

**Test de Kruskal Wallis 


\subsection{Empirical Model and Estimation}

A Multiple linear regression is used to express the relationship between students' performance, and the set of predictor, like, class size, hours studied per day, entry qualification, age, Gender, status, Area, family income, parents' education, and English aptitude. The basic academic achievements function was specified in the form:

$$
\begin{aligned}
& \text { GPA }=\alpha+\beta_{1} \text { Like }+\beta_{2} \text { Size }+\beta_{3} \text { Hours }+\beta_{4} \text { AveSec }+\beta_{5} \text { Age }+\beta_{6} \text { Gender }+\beta_{7} \text { Status }+\beta_{8} \text { Area }+\beta_{9} \text { Partedu }+\beta_{10} \text { Income }+ \\
& \beta_{11} \text { Family }+\beta_{12} \text { English }+u_{i}
\end{aligned}
$$

Where, Like is the student's learning preferences, Size is the class size, Hours is the number of daily study hour, AveSec is the entry qualification to university, Age is the age of each students, Gender is the sex of students, Status is the civil status, Area is residential area of student (distance to university), Partedu is the parents' education level, Family is the family size and English is the English language level of students.

\section{Results and Interpretation}

Overall, the estimated model indicated that about 31\% variation in student's academic performance was influeted by Student's learning preferences, class size, number of daily study hour, entry qualification to university, age, gender, civil status, residential area of student, parents' education level, family size and English language level. As showed by the model's F-test, the model was highly significant.

We cannot reject that Student's learning preferences positively affect student's achievement, for the whole sample and for female students only, Like, hasn't a statistically significant influence on male students' achievements. The class size has a negative effect on whole student's attainments, but the t-value is insignificant. The estimated effect of studying indicates that an additional hour of studying per day causes first semester grade point average to increase by 2.77 for female student and by 5 for male student. A test of the null hypothesis that studying has no effect on GPA can be rejected.

The estimated effect of Secondary Average on students' performance was significant and positive. The age has a negative effect on students' achievements, but the t-value is also insignificant. The variable Gender has a significant effect, Female perform better than male students. This result can be explained by the fact that male students often do part time jobs while girls have least opportunity to indulge in these types of jobs because they are not allowed by their parents. Married female Students realize significantly more academic success than single. Therefore, the null hypothesis that single students are more able to success than married students can be rejected. Residential area of student, and family size had a positive effect on students' overall academic achievement, but these variables are insignificant. Family income and Parents' education level has a negative effect, the t-value is also insignificant. The hypotheses that there are no significant effects in achievement based on those variables was accepted. English language level has a positive influence on students' academic performance for the whole sample and for female students, hence improvement in quality of English language leads to a 5.88 units improvement in female students' achievements, the effect become insignificant for the male sample. The Variance Inflation factor for all independent variables is between 1 and 1,034, we don't have a collinearity problem between independent variables. Durbin Watson shows that observations are independent $(\mathrm{DW}=2)$.

Table 3. Regression Results For Students' Performance, Dependent variable

\begin{tabular}{|c|c|c|c|}
\hline & All & Female & Male \\
\hline \multirow{2}{*}{$\begin{array}{l}\text { Independent } \\
\text { Variables }\end{array}$} & Coefficients & Coefficients & Coefficients \\
\hline & (T-Student) & (T-Student) & (T-Student) \\
\hline \multirow{2}{*}{ Constant } & 0.05 & $-21,01$ & 19,38 \\
\hline & $(0.00)$ & $(-0,51)$ & $(0,54)$ \\
\hline \multirow{2}{*}{ Like } & 8.09 & 9,88 & 0,89 \\
\hline & $(2.44)$ & $(2,57)$ & $(0,14)$ \\
\hline \multirow{2}{*}{ Size } & -0.03 & 0,02 & $-0,19$ \\
\hline & $(-0.244)$ & $(0,10)$ & $(-1,00)$ \\
\hline \multirow{2}{*}{ Hours } & 3.4 & 2,77 & 5,00 \\
\hline & $(3.25)$ & $(2,12)$ & $(2,75)$ \\
\hline \multirow{2}{*}{ AveSec } & 0.49 & 0,75 & 0,41 \\
\hline & $(3.56)$ & $(2,90)$ & $(2,46)$ \\
\hline \multirow{2}{*}{ Age } & -0.50 & $-0,47$ & 0,20 \\
\hline & $(-0.75)$ & $(-0,48)$ & $(0,21)$ \\
\hline \multirow{2}{*}{ Gender } & 11.87 & - & - \\
\hline & $(5.18)$ & & \\
\hline \multirow{2}{*}{ Status } & -7.01 & $-8,01$ & 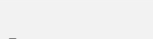 \\
\hline & $(-2.01)$ & $(-2,20)$ & - \\
\hline \multirow{2}{*}{ Area } & 1.17 & 0,17 & 2,19 \\
\hline & $(0.62)$ & $(0,06)$ & $(0,81)$ \\
\hline \multirow{2}{*}{ Partedu } & -0.44 & $-4,13$ & 1,97 \\
\hline & $(-0.23)$ & $(-1,41)$ & $(0,67)$ \\
\hline \multirow{2}{*}{ Family } & 0.16 & 0,94 & $-0,66$ \\
\hline & $(0.41)$ & $(1,65)$ & $(-1,22)$ \\
\hline \multirow{2}{*}{ Income } & -0.0003 & 0,46 & $-1,89$ \\
\hline & $(-0.17)$ & $(0,13)$ & $(-0,64)$ \\
\hline \multirow{2}{*}{ English } & 4.83 & 5,88 & 2,64 \\
\hline & (3.12) & $(2,49)$ & $(1,22)$ \\
\hline R-Squared & 0.31 & 0,23 & 0,13 \\
\hline F-test & 10.86 & 3,61 & 2,011 \\
\hline P-Value & 0.000 & 0,000 & 0,037 \\
\hline Observations & 288 & 143 & 145 \\
\hline
\end{tabular}
is student' GPA.

\section{Conclusion}

This study targets at exploring influences of factors affecting university students' academic progress. This study also aims at finding influences of above mentioned factors on both the genders.

Our findings are supported by various researches such as Farooq, Chaudhry and Berhanu (2011) and came up with the 
results that "the higher level of secondary average is the best indicator towards the quality of students' achievement". We report a significant relationship between success and the number of hours of studying per day.

Female students are performing well than the male students such as Ceballo. McLoyd and Toyokawa (2004) who say "students gender strongly affects their academic performance with girls performing better". The Students with good competence in English perform well.

According to the results of this study, we can recommend certain suggestions to improve the academic performance of the students. There should be committees consisted on educated persons to improve the environment of the college, provide effective learning, guide students whose parents cannot provide them a guide line in the educational problems. University should enrich the horizons of knowledge of ignorant parents and make them realize that education is as necessary for them as for their children.
Parental education is very important for best student's academic performance.

We can expect same results elsewhere, students at Education College have academic characteristics that are similar to those that attend other college and university in the region.

This study only focused on some of the factors that may contribute in the academic success of students, it can be improved by incorporating more factors, teaching methods and quality of learning materials.

The comprehensible understanding of the above factors is very significant. Furthermore, including some other factors that affect the student's achievement can improve our results.

\section{Acknowledgements}

The authors gratefully acknowledge the education college at Dammam University (Saudi Arabia) for agreed to the distribution of the survey instrument.

\section{Appendix}

Table A1. The Correlation Matrix.

\begin{tabular}{|c|c|c|c|c|c|c|c|c|c|c|c|c|c|c|}
\hline & Field & Like & Freq & Hours & AveSec & Age & Gender & Status & Area & Income & Partedu & Family & averp & English \\
\hline Field & 1 & $0,21^{* *}$ & $0,25^{* *}$ & $-0,10$ & 0,06 & $-0,01$ & $-0,14^{*}$ & $-0,07$ & 0,04 & 0,02 & $-0,04$ & $0,17^{* *}$ & 0,07 & 0,07 \\
\hline Like & $0,21^{* *}$ & 1 & 0,05 & $-0,10$ & 0,02 & 0,04 & $-0,15^{*}$ & 0,02 & 0,03 & 0,03 & 0,06 & 0,05 & 0,04 & $-0,12^{*}$ \\
\hline Freq & $0,25^{* *}$ & 0,05 & 1 & 0,05 & $0,22^{* *}$ & $-0,01$ & $0,22^{* *}$ & 0,10 & $-0,05$ & 0,09 & $-0,13^{*}$ & 0,04 & $0,13^{*}$ & 0,11 \\
\hline Hours & $-0,10$ & $-0,10$ & 0,05 & 1 & $0,12^{*}$ & 0,03 & $0,38^{* *}$ & $0,12^{*}$ & $-0,10$ & $-0,03$ & 0,07 & $-0,01$ & $0,29^{* *}$ & $-0,01$ \\
\hline AveSec & 0,06 & 0,02 & $0,22^{* *}$ & $0,12^{*}$ & 1 & 0,04 & $0,35^{* *}$ & $0,14^{*}$ & $-0,06$ & $0,12^{*}$ & 0,00 & 0,10 & $0,34^{* *}$ & $0,13^{*}$ \\
\hline Age & $-0,01$ & 0,04 & $-0,01$ & 0,03 & 0,04 & 1 & $-0,04$ & $0,25^{* *}$ & $-0,02$ & $-0,03$ & 0,10 & $0,19^{* *}$ & $-0,05$ & 0,10 \\
\hline Gender & $-0,14^{*}$ & $-0,15^{*}$ & $0,22^{* *}$ & $0,38^{*}$ & $0,35^{* *}$ & $-0,04$ & 1 & $0,30^{* *}$ & $-0,01$ & 0,11 & $-0,04$ & 0,01 & $0,45^{* *}$ & $0,21^{* *}$ \\
\hline Area & 0,04 & 0,03 & $-0,05$ & $-0,10$ & $-0,06$ & $-0,02$ & $-0,01$ & 0,03 & 1 & 0,07 & 0,00 & 0,06 & 0,03 & $0,13^{*}$ \\
\hline Income & 0,02 & 0,03 & 0,09 & $-0,03$ & $0,12^{*}$ & $-0,03$ & 0,11 & $-0,08$ & 0,07 & 1 & $-0,39 * *$ & $-0,04$ & 0,08 & 0,09 \\
\hline Partedu & $-0,04$ & 0,06 &,$- 13^{*}$ & 0,07 & 0,00 & 0,10 & $-0,04$ & 0,07 & 0,00 & $-0,39 * *$ & 1 & 0,11 & $-0,03$ & $-0,09$ \\
\hline Family & $0,17^{* *}$ & 0,05 & 0,04 & $-0,01$ & 0,10 & $0,19^{* *}$ & 0,01 &, $141^{*}$ & 0,06 & $-0,04$ & 0,11 & 1 & 0,02 & $-0,01$ \\
\hline averp & 0,07 & 0,04 & $0,13^{*}$ & $0,29^{* *}$ & $0,34^{* *}$ & $-0,05$ & $0,45^{* *}$ & 0,05 & 0,03 & 0,08 & $-0,03$ & 0,02 & 1 & $0,23 * *$ \\
\hline English & 0,07 & $-0,12^{*}$ & 0,11 & $-0,01$ & $0,13^{*}$ & 0,10 & $0,21^{* *}$ & 0,10 & $0,13^{*}$ & 0,09 & $-0,09$ & $-0,01$ & $0,23^{* *}$ & 1 \\
\hline
\end{tabular}

\section{References}

[1] Anderson G. and Benjamin D. (1994). The determinants of success in university introductory economics courses. The Journal of Economic Education. vol. 25 (2).

[2] Aslam H. D. Younis A. Shiekh A. A. Maher. M. and Abbasi Z. A. (2012). Analyzing factors effecting student's satisfaction regarding semester system in universities of Pakistan. Middle East journal of Scientific Research.

[3] Ballatine J. H. (1993). The sociology of education: A systematic analysis. Englwood Cliffs: Prentice Hall. Adv Health Sci Educ Theory Pract. 2000. vol. 5 n $^{\circ} 3$.

[4] Battle J. and Lewis. M. (2002). The increasing significance of class: The relative effects of race and socioeconomic status on academic achievement. Journal of Poverty, vol. $6, n^{\circ} 2$.

[5] Borde S. F. (1998). Predictors of student academic performance in the introductory marketing course. Journal of Education for Business, 73 (5).

[6] Darling N. Caldwell L. L. and Smith R. (2005). Participation in school-based extracurricular activities and adolescent adjustment. Journal of Leisure Research, vol. 37.

[7] Elvis Munyaradzi G. (2013). Factors Influencing Academic Achievement in Quantitative Courses among Business Students of Private Higher Education Institutions. Journal of Education and Practice, vol. 4. $\mathrm{n}^{\circ}$. 15. 2013.

[8] Farooq M. S., Chaudhry A. H., Shafique M. and Berhan. G. (2011). Factors effecting student's quality of academic performance a case of secondary school level. Journal of quality and technology management.

[9] Galiher. S. (2006). Understanding the effect of extracurricular involvement. A Research Project Report Presented to the School of Education Indiana University South Bend In Partial Fulfillment of the Requirements for the Degree Master of Education.

[10] Haist S. A., Wilson J. F., Elam C. L., Blue A. V., and Fosson, S. E. (2000). The effect of gender and age on medical school performance: An important interaction. Advances in Health Sciences Education, 5 (3).

[11] Harb. N. and El-Shaarawi. A. (2006). Factors Affecting Students' Performance. Journal of Business Education. vol. 82. $n^{\circ} 5$. 
[12] Ilie S. and Lietz P. (2010) IERI Monograph, School quality and student achievement in 21 European countries: 57 The Heyneman-Loxley effect revisited, Series Issues and Methodologies in Large-Scale Assessments, vol. 3.

[13] McKeachie W. J. (1980). Class Size, Large Classes and Multiple Sections," Academe (2).

[14] McKeachie W. J., Asghar Iran-Nejad, and David C. Berliner. (1990). The Multi-source nature of learning: An

[15] Introduction, Review of Educational Research 60 (4).

[16] Memon. G. R. Joubish. M. F. and Khurram. M. A. (2010). Impact of parental socio-economic status on student's educational achievements and secondary schools of district Malir. Karachi.

[17] Musarat A. Sundus N. Faqiha N. Fozia P. and Ayesha S. (2013). Impact of parental education and socio-economic status on academic achievements of University students. International Journal of Academic Research and Reflection, vol. $1 \mathrm{n}^{\circ} .3$.

[18] Pascarella E. T. and Terenzini P. T. (1991). How college affects students: Findings and insights from twenty years of research. San Francisco: Jossey-Bass.

[19] Pascarella E. T. and Terenzini P. T. (2005). How college affects students. Vol. 2: A third decade of research. San Francisco: Jossey-Bass.
[20] Richardson. V. (1994). Conducting research on practice. Educational Researcher. Vol. 23. no 5.

[21] Romer D. (1993). Do Students Go to Class? Should They? Journal of Economic Perspectives. vol. 7, no. 3.

[22] Trueman M. and Hartley J., (1996). A comparison of the timemanagement skills and academic performance of mature and traditional-entry university students. Higher Education, 32 (1996).

[23] Victor M. (2011). An analysis of some factors affecting student academic performance in an introductory biochemistry course at the University of the West Indies. Caribbean Teaching Scholar, vol. 1. n ${ }^{\circ} .2$.

[24] Waters T. J. and Marzano R. J. (2006). School district leadership that works: The effect of superintendent leadership on student achievement. Mid-Continent Research for Education and Learning.

[25] Williams David D., Paul F. Cook, Bill Quinn and Randall P. Jensen (1985). University Class Size: Is Smaller Better? Research in Higher Education 23 (3).

[26] Zimmerman B. and Martinez P. (1992). Self motivation for academic attainment: The role of Self-Efficacy Beliefs and Personal Goal Setting. American Educational Research Journal, vol 29. $n^{\circ} 3$. 